\title{
Veljko Maksić
}

(Vera)

\section{PRAVOSLAVNO SVEĆENSTVO SLAVONIJE I SRIJEMA U BORBI S KUGOM TIJEKOM XVIII. STOLJEĆA}

\author{
UDK 616.98:281(497.5 Slavonija)“17““ \\ 616.98:281(497.5 Srijem)“"17“ \\ Izvorni znanstveni rad \\ Primljeno: 15. 2. 2019.
}

\begin{abstract}
Stanovnik slavonsko-srijemskog područja XVIII. stoljeća imao je nesreću da nekoliko puta svjedoči strahotama epidemije kuge. Promet robe i ljudi kroz pogranično područje, kakvo je bilo ovo slavonsko-srijemsko, za sobom je nosio i rizik prijenosa bolesti. U namjeri sprječavanja širenja epidemija kuge, Habsburška Monarhija je tijekom XVIII. stoljeća izgradila sustav sanitarnog kordona koji je trebao zaustaviti širenje zaraze na granicama države. Unatoč svim mjerama opreza, širenje zaraze preko linije razgraničenja nije uvijek bilo moguće spriječiti. Nepoznavanje uzročnika kuge, kao niti pouzdanog lijeka, stanovništvo zaraženog područja tjeralo je u očajanje pred nemilosrdnošću kuge. Jedini spas stanovništvo je moglo očekivati zazivanjem Boga i nadati se pomoći istoga. Cilj rada je opisati ulogu pravoslavnog svećenstva u okolnostima u kojima se stanovništvo moglo nadati isključivo božjoj pomoći. U radu je najprije objašnjeno shvaćanje epidemije kuge među suvremenicima, to jest tumačenje zaraze kao božje kazne ili djelovanja demona. Na tu cjelinu nastavlja se prikaz duhovne brige svećenstva, izražene kroz molitve. Utjecaj svećenstva na stanovništvo nastojale su iskoristiti svjetovne vlasti, te su tako angažirale pravoslavno svećenstvo u cilju plasiranja i eksplanacije svrsishodnosti pojedinih sanitarnih mjera. Interakcija svećenstva sa stanovništvom u vrijeme haranja kuge zahtijevala je prilagodbu i same svećeničke prakse. Na koncu, prikazana je uloga svećenstva u medicinskoj djelatnosti.
\end{abstract}

Ključne riječi: kuga, Slavonija, Srijem, pravoslavno svećenstvo, XVIII. stoljeće 


\section{Uvod}

Opravdanost titule jednoga od četiriju jahača apokalipse nalazimo u opisu kuge koji je ostavio Petar Runjanin. Pišući o tzv. iriškoj kugi s kraja XVIII. stoljeća 40-ak godina kasnije, ali prema vlastitom svjedočanstvu, zabilježio je: „Sama pomisl na kugu strašna je, a kad još oko nas vidimo nesretne žrtve, koje od ove strašne bolesti padaju, zdrava čoveka, pri samom pomislu smrtna groznica obuzme. A može li što užasnije biti, nego, kad roditelji milu decu svoju u strašnoj smrtnoj muci bezpomoćnu ostave, kada deca od roditelja beže, da izbave se javne pogibije....". ${ }^{1}$ Runjaninov opis upotpunjuju riječi iriškog svećenika Stevana Vezilića, koji je na evanđelju svetonikolajevske crkve u Irigu, nakon jenjavanja epidemije, zabilježio kako ,je na dan po 20-30-35 duša umiralo. I toj bolesti, tj. kugi, drugog leka nema, kromje ako se koji razbole, to tako njega u špitalj, a drugi iz kuće neka beže. Ako se bolestni od zdravih ne uklone, to svi do jednog pomreti moraju“.2

Suočen sa svakodnevnom smrću na epidemičnom području, a svjedok nedovoljno učinkovitih medicinskih postupaka, ${ }^{3}$ čovjek XVIII. stoljeća spas je mogao očekivati tek u zazivanju božje pomoći ili u potrazi za nekim drugim iracionalnim rješenjima. Kao nijemi svjedoci vremena kada su živi zavidjeli mrtvima, ostali su mnogobrojni sakralni i zavjetni objekti podignuti tijekom vladanja epidemija kuge, prije ili neposredno nakon nje. Dakako, primat u toj pojavi imale bi svetinje posvećene svecima zaštitnicima od te bolesti. Zasigurno nije slučajnost što je u crkvi svetog Jurja u Petrovaradinu 1701. godine izgrađen oltar posvećen Blaženoj Djevici Mariji, kao zaštitnici od svih bolesti. Na isti oltar kasnije je dodana ikona Snježne Gospe, smještena između kipova svetog Roka ${ }^{4}$ i svetog

${ }^{1}$ Stevan Bugarski, „Podaci o sremskoj kugi u zapisima Save Tekelije pri Madžarskoj dvorskoj kancelariji“, u: Zbornik radova: 200-godišnjica sremske-iriške kuge, ur. Vojislav Jovanović (Novi Sad: Naučno društvo za istoriju zdravstvene kulture Vojvodine, 1996), 30.

2 Jovan Maksimović, Srem u vreme kuge (Irig: Srpska čitaonica u Irigu, 2015), 34.

${ }^{3}$ Sve do kraja XIX. stoljeća uzročnik kuge je bio nepoznanica. Tada su prilikom izučavanja epidemije kuge u Hong Kongu 1894. godine Švicarac Alexandre Yersin te, neovisno od njega, Japanac Shibasaburo Kitasato otkrili i opisali uzročnika kuge. Uzročnik je kasnije u medicinsku literaturu ušao s imenom Yersinia pestis. Otkrivanjem uzročnika kuge udaren je temelj uspješnom liječenju zaraze. Maksimović, Srem u vreme kuge, 15; Petar Mikić, „Kuga u Karlovcima 1738-1740 i 1795/96“, Krovovi - bilten za kulturu i umetnost 21 (2007), br. 67/70, 25; Gordan Ravančić, Crna smrt 1348.-1349. u Dubrovniku. Srednjovjekovni grad i doživljaj epidemije (doktorska disertacija, Sveučilište u Zagrebu, 2006), 1; Željko Cvetnić, Bolesti koje su mijenjale svijet (Zagreb: Medicinska naklada, Hrvatski veterinarski institut, 2018), 115.

${ }^{4}$ Bruno Atalić smatra kako su sveti Sebastijan i sveti Rok ,povezani s epidemijama kuge samo simbolički, prvi zato što su strijele koje su ga probole percipirane kao simboli Božjeg gnjeva na grješno čovječanstvo koje je zbog toga kažnjeno epidemijama kuge, između ostalih nedaća, a drugi zato što čir na njegovoj nozi podsjeća na bubus tipičan za pandemiju Crne smrti koja se pojavila nedugo nakon njegove smrti“. Bruno Atalić, ,Spomenik Presvetoga Trojstva u gradu Osijeku“, Acta medico-historica Adriatica 15 (2017) br. Supplement 1: 88, 90. Ipak, 
Sebastijana, ${ }^{5}$ zaštitnika od kuge. ${ }^{6}$ Izraženost štovanja zaštitnika od kuge vidljiva je i u filijalnoj kapeli u Novom Vukovaru, posvećenoj svetom Roku, podignutoj još 1740. godine. Na oltaru kapele našla se slika svetog Roka, a sa strane svete Rozalije $^{7}$ i svetog Sebastijana. ${ }^{8}$ Iz kanonskih vizitacija osječkog Donjeg grada 1761. godine saznajemo kako je kapelu svetog Roka ,podigla gradska općina po dopuštenju biskupa kao zavjetnu u vrijeme kuge“. ${ }^{9}$ Isto tako, prilikom vizitacije župe Valpovo 1829. godine zabilježeno je kako je „kapela svetog Roka ispovjednika, podignuta iz zavjeta prilikom haranja kuge u Srijemu 1795. godine od časnog vlastelinstva i blagoslovljena od okružnog vicearhiđakona“. ${ }^{10}$ To bi odgovaralo onome što je Bruno Atalić rekao o osječkom kužnom pilu, kao i ostalim u Habsburškoj Monarhiji, da se njihova gradnja može ,,protumačiti kao simbol teurgičkoga pristupa epidemijama kuge koje su prema takvim objašnjenjima doživ-

Atalićevo mišljenje može se samo djelomično prihvatiti, jer povezanost svetoga Roka s epidemijama kuge je nešto složenija. Prema legendi, sveti Rok se rodio u Montpellieru u Francuskoj. Po smrti svojih roditelja dijeli imovinu i odlazi na hodočašće u Rim. Na tom putu došao je u grad Acquapendente, u kojem je harala kuga. Sveti Rok se prihvatio njegovanja oboljelih, od kojih su se mnogi oporavili. Smatrajući kako je Bog njemu namijenio sudbinu onoga koji će pomagati oboljelima od kuge, krenuo je „za kugom“ kako bi liječio oboljele. U stalnom dodiru s okuženima, sveti Rok se i sam zarazio kugom u Piacenzi. Uslijed zaraze povukao se u šumu kako bi na miru dočekao sudbonosan kraj. Međutim, njegov pas mu je svakodnevno donosio kruh u šumu, tako da se svetac s vremenom oporavio, ali ga je bolest izmorila do neprepoznatljivosti. Došavši u rodni grad, vlastiti ga je ujak, tamošnji sudac, zatvorio kao skitnicu jer ga nije poznao. Nakon petogodišnjeg tamnovanja sveti Rok je preminuo, ostavivši u svojoj ćeliji natpis „Svi koji obole od kuge i zatraže pomoć od sv. Roka, sluge Božjega, biće izlečeni“. Jovan Maksimović, „Kuga u kulturnoistorijskim spomenicima“, u: Zbornik radova: 200-godišnjica sremske-iriške kuge, ur. Vojislav Jovanović (Novi Sad: Naučno društvo za istoriju zdravstvene kulture Vojvodine, 1996), 66; Frederick Cartwright, Michael Biddiss, Bolest i povijest, prev. Lucija Horvat (Zagreb: Naklada Ljevak, 2006), 53.

${ }^{5}$ Sveti Sebastijan je rođen u Narboni u Galiji tijekom III. stoljeća. Unatoč tome što je bio zapovjednik pretorijanaca, bio je kršćanin; dakako, prikriveni. Po otkriću njegove religijske opredijeljenosti, car Dioklecijan dao ga je pogubiti strelicama. Međutim, Sebastijan je preživio likvidaciju te se i uspješno oporavio od zadobivenih ozljeda. Nakon oporavka Sebastijan je počeo otvoreno propovijedati kršćanstvo, što nije promaklo caru. I ovoga puta car je Sebastijanu namijenio istu sudbinu te je naredio da uhvaćenog mladića odvedu u arenu i pogube, a potom njegovo tijelo bace u odvodni rimski kanal. Sveti je Sebastijan epitet zaštitnika kuge dobio zbog preživljavanja likvidacije strelicama. Naime, u antici i srednjem vijeku postojalo je uvjerenje kako se kuga prenosi pomoću Apolonovih strelica. Maksimović, „Kuga u kulturnoistorijskim spomenicima“, 68; Ravančić, Crna smrt 1348.-1349. u Dubrovniku, 5.

${ }^{6}$ Maksimović, Srem u vreme kuge, 23.

${ }^{7}$ Sveta Rozalija (1130. - 1160.) štuje se kao zaštitnica od kuge zbog njezine povezanosti sa suzbijanjem epidemije kuge u Palermu 1624. godine. Naime, ona se ukazala vidiocu u snu te ponudila svoju pomoć uz uvjet da se dostojno pokopaju njezine izgubljene kosti. Atalić, „Spomenik Presvetoga Trojstva u gradu Osijeku“, 91.

${ }^{8}$ Stjepan Sršan, ur., Kanonske vizitacije, knj. 8 (Osijek: Državni arhiv u Osijeku, 2010), 499.

9 Stjepan Sršan, ur., Kanonske vizitacije, knj. 5 (Osijek: Državni arhiv u Osijeku, 2007), 45.

${ }^{10}$ Stjepan Sršan, ur., Kanonske vizitacije, knj. 3 (Osijek: Državni arhiv u Osijeku, 2005), 513. 
ljavane kao božja kazna za grješno čovječanstvo" “. ${ }^{11}$ Dakako, niz sakralnih spomenika posvećenih zaštitnicima od kuge ovim nabrajanjem nije okončan, nego je samo skrenuta pozornost na brojnost istih na slavonsko-srijemskom prostoru, što je opet posljedica realne i česte prijetnje epidemija kuge tijekom XVIII. stoljeća.

No, podizanje spomenika posvećenih zaštitnicima od kuge, odnosno sam razvoj kulta svetaca zaštitnika, uglavnom izostaje kod pravoslavaca na istom prostoru, iako je potreba za zaštitom bila jednako nužna. Među rijetkim je svecima koji se dovode u korelaciju sa zaštitom od kuge sveti Haralampije, štovan u Irigu. Naime, na praznik ovog sveca (10. 2. po julijanskom kalendaru) kuga je konačno 1796. godine završila svoje haranje po Irigu, zbog čega je i štovan. Još jedan vid štovanja ogleda se u tome što su mnoga novorođena djeca u Irigu po prestanku epidemije ponijela ime Haralampije. ${ }^{12}$

Kakav je bio odnos pravoslavaca prema epidemijama kuge možda je najbolje vidljivo kroz aktivnosti pravoslavnog svećenstva kao posrednika između vjernika, svjetovne vlasti i Boga u vrijeme epidemija kuge. Shodno tome, cilj rada je prikazati ulogu pravoslavnog svećenstva u borbi s kugom na slavonsko-srijemskom prostoru XVIII. stoljeća. Kako bi se razumjela uloga svećenstva u akcijama suzbijanja epidemija kuge XVIII. stoljeća, nužno je imati uvid u shvaćanje kuge među suvremenicima. Na to se nadovezuje prikaz duhovne brige svećenstva za svoju pastvu u vrijeme epidemija. Svećenstvo XVIII. stoljeća među lokalnim stanovništvom uživalo je poštovanje. Upravo zbog svoga autoriteta svjetovne vlasti su smatrale korisnim pridobiti svećenstvo, odnosno koristiti ga kao posrednika na relaciji država-narod, s ciljem provođenja sanitarnih mjera. Stalni kontakt s osobama na okuženom prostoru zahtijevao je određene prilagodbe i u svećeničkoj praksi, što je prikazano u narednoj cjelini. Zadnja cjelina posvećena je općenitoj ulozi svećenstva u medicinskoj praksi, odnosno njihovom doprinosu.

\section{Tumačenje kuge kao božje kazne}

Nasljeđe tumačenja Starog zavjeta, posebice priče o Ninivi, gdje se nedaće tumače kao kazna Svevišnjeg nad grešnim narodom bilo je rasprostranjeno širom Europe ranog novog vijeka. Iz toga razloga i epidemije su tumačene kao djelovanje Boga. Između ostalih, Martin Luther kugu je tumačio kao božju kaznu i opomenu. ${ }^{13}$ Još upečatljivije su riječi francuskog liječnika Ambroisea Parea (oko 1510.-1590.), koji za kugu kaže da je „bič gnjeva Božijeg, (i) si-

\footnotetext{
${ }^{11}$ Atalić, „Spomenik Presvetoga Trojstva u gradu Osijeku“, 84.

12 Milan Jovanović, Iz prošlosti Iriga (Irig: Srpska čitaonica, 1922), 7.

${ }^{13}$ Jean Delumeau, Strah na zapadu, prev. Zoran Stojanović (Vrnjačka Banja: Zamak kulture, 1982), 104.
} 
gurno je da smo ogrezli u krajnjem zlu, kad su toliki naši gresi naveli njegovu milost da povuče svoju milosrdnu ruku sa nas i pošalje nam takvu propast" ${ }^{\prime 14}$ Ništa drugačije ne misli ni jedan od 12 liječnika marsejskog kolegija liječnika, koji je uzroke pojave kuge 1720. godine pronašao u ,iskvarenosti onih koji je nastanjuju, jer su prekršili svete zakone“"!15

Slična tumačenja epidemija kuge možemo pronaći među pravoslavnim svećenstvom u Slavoniji i Srijemu tijekom XVIII. stoljeća. Ravanički pisac i svjedok tzv. erdeljske kuge zabilježio je kako „V ova leta (1738. godine, op. a.) voinstvena jegda pojde Nemac na Turčina pre roka, togda postiže nas pravedni gnev božiji, i posla preblagi Bog kugu, naprasnuju smrt i bolezan, na narod i deržavu cesarsku..." ${ }^{16}$ Misao o božjoj kazni prenio je, više od pola stoljeća kasnije (1796.), u cirkularnom pismu i episkop pakračko-slavonski Kiril Živković objašnjavajući kako „Ova bolest (kuga, op. a.) ako se od Boga radi velikih greha šalje na narod“ “. ${ }^{17}$ Katoličko svećenstvo slavonsko-srijemskog prostora podržavalo je isto tumačenje. Primjerice, u kronici franjevačkog samostana u Slavonskom Brodu za 1740. godinu kuga je opisana kao „bič Božji““. ${ }^{18}$

Providencijalističko tumačenje kuge nije bilo nepoznato ni predstavnicima svjetovne vlasti. U Pest-patentu iz 1710. godine, jednom od prvih patenata koji donosi opis zaraze kuge i upute kako pomoći zaraženom, naglašava se bogobojazan odnos ,prema Bogu, da bi se dobrim djelima izbjegla zaslužena teška kazna; trijezno prema sebi, da bi se izbjegla teška jela i neumjeren život, te pravedno prema drugome, kako bi mu se najbolje moglo uskočiti u pomoć u nuždi““ ${ }^{19}$ S̆toviše, sam car Karlo VI. smatrao je kugu božjom kaznom za nemoralni život stanovništva. ${ }^{20}$

Za ovo tumačenje bitno je da se ono javlja kao odgovor na čovjekovo ponašanje iz prošlosti. U trenucima provedbe „kazne“ retroaktivno se pronalaze grijesi iz prošlosti, koje je bez puno truda uvijek moguće naći, te se oni

14 Isto, 104.

${ }^{15}$ Francois Walter, Katastrofe. Jedna kulturna istorija od XVI do XXI veka, prev. Tamara Valčić Bulić (Novi Sad: Akademska knjiga, 2012), 49.

${ }^{16}$ Ljubomir Stojanović, ur., Stari srpski rodoslovi i letopisi (Sremski Karlovci: Srpska kraljevska akademija, 1927), 317.

${ }^{17}$ Miroslav Milošević, Dušan Novaković, Ivka Novaković, „Propisi za borbu protiv kuge u Pakracu 1796. godine“, Farmaceutski glasnik 35 (1979), br. 6, 200.

${ }^{18}$ Egidije Stjepan Biber, ur., Kronika Franjevačkog samostana u Brodu na Savi, knj. 1 (Slavonski Brod: Matica Hrvatska, Ogranak Slavonski Brod; Franjevački samostan Slavonski Brod; Povijesni arhiv Slavonki Brod, 1995), 89.

${ }^{19}$ Ivana Horbec, Zdravlje naroda - bogatstvo države. Prosvijećeni apsolutizam i počeci sustava javnoga zdravstva u Hrvatskoj (Zagreb: Hrvatski institut za povijest, 2015), 235-236.

${ }^{20}$ Robert Skenderović, Utjecaj terezijanskih reformi na demografski razvoj slavonskog Provincijala (doktorska disertacija, Sveučilište u Zagrebu, 2005), 243. 
tumače uzrokom proživljavanog stanja. Treba se prisjetiti samo primjera gdje ravanički pisac zaključuje kako je epidemija došla kao kazna za nepoštivanje mirovnog ugovora od strane bečkog dvora.

Providencijalističko tumačenje kuge imalo je oprečna shvaćanja. Jedno od njih kugu je vidjelo kao božju opomenu s namjerom izazivanja pokore grešnog stanovništva. Drugo prihvaćeno shvaćanje je kako se protiv kuge ne vrijedi boriti, jer bi se time išlo protiv volje samog Svevišnjega, koji ju je poslao na grešan narod. Ovo posljednje, s aspekta sanitarnih mjera, bilo je vrlo problematično. Ravnodušnost prema sanitarnim mjerama, odnosno nepotrebno izlaganje potencijalnoj zarazi u iščekivanju konačnog suda, samo su pogodovali širenju kuge. Stoga ne iznenađuje što su mnogobrojni apeli svjetovnih i crkvenih vlasti temeljeni na kršćanskoj samoodrživosti. Istu su naglašavali Joseph Pichler i Franz von Schraud, odgovorni za organizaciju sanitarnih mjera tijekom tzv. iriške kuge, u proglasu Kratko uputstvo kako se od kuge sačuvati može, igrajući na pobožnost naroda, te su neprovođenje sanitarnih mjera predstavljali kao djelo protiv samoga sebe, ali i ,protivu samago Boga“ ${ }^{21} \mathrm{Na}$ tragu toga su i riječi karlovačkog mitropolita Stefana Stratimirovića, koji je u pismu datiranom 20. prosinca 1795. godine (po julijanskom kalendaru) poručivao svećenicima obznanjivanje narodu kako je onaj koji se protivi sanitarnim mjerama oprečan božjoj volji ,jerbo črez njegovu nepokornost bolest se rasprostranjava, toliko Hristijanstvo umire, i cjelo Carstvo u napast se meće“, dalje navodeći da takve osobe, „koji črez njiovu nepokornost toliku zlu uzrok bivaju, nikada lica Božija vidjeti neće". ${ }^{22}$ Takve osobe će, po mitropolitovim riječima, „pod vječitu Cerkovnu Anatemu metuti, nji sa svi iz Cerkve izključiti, i kako što tjelom propadaju, tako i duši ih pod vječitoje žizni očajanije da padnut “. ${ }^{23}$ Mitropolit nastavlja: „da promisle i to, kako može onakovi Hristijanin kakovoj sreći ot Boga nadati se, koji upravo protivu Božije volje ide, ne pokoravajući se vlasti, i neslušajući Cerkvu, koja im toliko puta to nalaže, jerbo koji se protivi vlasti ot Boga pokorenoj, taj se protivi i samomu Bogu“".24

Slično se može iščitati iz pisma grgeteškog arhimandrita Stefana Avakumovića rumskom namjesniku Vasiliju Krstiću studenoga 1795. godine. Arhimandrit poručuje da se po njegovom namjesništvu obznani kako onaj koji se protivi sanitarnim mjerama, primjerice prikrivajući pojavu kuge u svome

${ }^{21}$ Franz von Schraud, Joseph Pichler, Краткое поученїе како отъ куги сачуватися мощии, 1795., pristup ostvaren 11. 6. 2018. http://digital.bms.rs/ebiblioteka/pageFlip/reader/index. php? type $=$ publications $\&$ id $=560 \& \mathrm{~m}=2 \#$ page $/ 1 /$ mode $/ 2$ up;

${ }^{22}$ Vasa Krstić, „Okružnice sveštenstvu za vreme kuge u Sremu 1795 i 1796 godine“, u: Prilozi za istoriju zdravstvene kulture Jugoslavije i Balkanskog poluostrva (Beograd: Biblioteka Centralnog higijenskog zavoda, 1940), 21.

${ }^{23}$ Isto, 21.

${ }^{24}$ Isto, 21. 
domu, ne radi samo štetu sebi samom, već i svojim bližnjima te „zato svakii takovii na strašnomu sudu, kakogod koji je čelovjeka ubio onako vječnija kazni pravednjeišago sudije Gda Boga“" ${ }^{25}$ Ne začuđuje što su crkveni predstavnici izjednačavali oglušivanje o sanitarne mjere s ubojstvom, to jest s jednim od smrtnih grijeha. Time se nastojalo utjecati na savjest vjernika, ako već ne shvaćaju korisnost sanitarnih mjera, barem da se izazove poštivanje istih iz religioznih pobuda i straha od božjeg suda.

U istom stoljeću dolazi do pomaka od providencijalističkog objašnjenja kuge. Povodom katastrofalnog zemljotresa koji je pogodio Lisabon sredinom XVIII. stoljeća francuski filozof Jean Jacques Rousseau s pravom se zapitao kolika je uloga samoga čovjeka u toj nesreći; bi li posljedice bile manje da je grad bio primjerenije naseljen ili građevinski drugačije uređen. ${ }^{26}$ Rousseauovo razmišljanje „,nas projektuje u novi period, ne tako što bi jednostrano prema ljudskom usmerila potragu za elementima objašnjenja bilo kakvog zla, već tako što iznosi na videlo međuzavisnosti koje postoje između prirode $i$ društva. Ne kažnjava više Bog, već grozničavost ljudskih delanja u svetu postaje kontraproduktivna kada dovodi u opasnost prirodne ravnoteže“ “. ${ }^{27}$ Razmišljanje francuskog filozofa podsjeća na ono srpskog prosvjetitelja Dositeja Obradovića (oko 1739.-1811.). Dositej se retorički pitao ,ima li Turčin pravo kad veli da ni od kuge ne valja bežati? Jok vala! U tom ima vrlo krivo. Od boga ne mogući uteći, ne valja ni da bežimo; a od požara, velike vode, kuge i drugih mnogih zala mogući se sačuvati i ne hoteći, vrlo ludo poslujemo" ${ }^{28} \mathrm{U}$ manirama prosvjetiteljstva, Dositej Obradović, kao i Rousseau, odgovornost za tragične posljedice prebacuje na čovjeka.

Prosvjetiteljske stavove pratilo je i zakonodavstvo bečkog dvora. Kada je druge polovice XVIII. stoljeća Heinrich Gottlob von Justi (1717.-1771.), austrijski teoretičar kameralizma, pisao „da se prije smatralo da je kuga Božja kazna kojoj se ljudski oprez ne može suprotsaviti nego joj se čovjek mora strpljivo pokoriti““ ${ }^{29}$ sudbonosni utjecaj kuge kao nečega nepromjenjivog odbačen je. Samim time se ne negira primat Boga, već je naglasak stavljen na svrsishodnost borbe protiv zaraze. Primjerice, u Općem zdravstvenom pravilniku iz 1770. godine i dalje se često naglašava kako liječnici, ljekarnici i drugo zdravstveno osoblje trebaju „njegovati kršćanski način života“30 i „da žive Bogu poćudnim

\footnotetext{
${ }^{25}$ Isto, 15.

${ }^{26}$ Walter, Katastrofe, 107.

${ }^{27}$ Isto, 107-108.

${ }^{28}$ Dositej Obradović, Život i priključenija, knj. I, ur. Goran Nakomčić (Novi Sad: Školska knjiga, 2004), 20.

${ }^{29}$ Horbec, Zdravlje naroda, 85.

${ }^{30}$ Isto, 258.
} 
životom“. ${ }^{31}$ Isto tako, zadržano je mišljenje kako je Bog onaj koji može sačuvati od zaraze ili je iskorijeniti; „u budućim razdobljima kuge i umiranja (neka nas Svemogući otkloni od njih) "32 ili iskorjenjivanje zaraznih bolesti „uz Božju pomoć“" ${ }^{33}$ Pored toga, istim je propisano da u kontumacima ,gdje god to dopuštaju okolnosti, da te osobe, pa i bolesnici, sudjeluju u svetim Sakramentima i dobivaju utjehu Svete Mise koliko je god često moguće, i to pod primjerenim ograničenjima u skladu s propisima i bez ikakvih kontakata“". ${ }^{34}$

U sklopu ovoga razmatranja bilo bi zanimljivo vidjeti i samu predodžbu kuge u narodu. Topografsko nasljeđe usmjerava na mišljenje da je i u narodu vladala kršćanska predodžba kuge. Naime, to proizlazi iz naziva jednog iriškog okrajka koji je ponio naziv „Sodom“, gdje ne treba posebno naglašavati asocijaciju na biblijsku temu. ${ }^{35}$ Međutim, iz nekih drugih pisanih ostavština zaključuje se potpuno suprotno. Sava Tekelija (1761.-1842.) zabilježio je kako Srijemci, tijekom epidemije iriške kuge, ,po običaju prostih počeli su govoriti da vampiri hode, i kuga u licu stare babe ${ }^{\text {". }}{ }^{36}$ Sličnu pojavu zabilježio je Radivoj Simonović u Irigu. On je u razgovoru s nekom Irižankom saznao za vjerovanje „da je kuga žena u belo obučena i da noću ide od kuće do kuće“. ${ }^{37}$ Spomenuti opis Simonović je pronašao na ikoni u jednoj iriškoj crkvi, na kojoj je naslikan svetac Haralampije ${ }^{38}$ kako desnicom blagoslivlja dok stoji na jednoj zgrčenoj ženi koja na glavi ima rogove, a na nogama kandže ${ }^{39}$ Identična priča o ženi kao personifikaciji kuge bila je prisutna i u Kamenici. ${ }^{40}$

Ovaj motiv javlja se i u zapadnom Srijemu. Pišući o životu u Otoku, Josip Lovretić donosi predodžbu kuge koja ,ima tilo ko i druge žene. Pod nom su

\footnotetext{
${ }^{31}$ Isto, 263.

${ }^{32}$ Isto, 260.

${ }^{33}$ Isto, 270

${ }^{34}$ Isto, 300.

35 Živko Marković, „Irižani o kugi“, u: Zbornik radova: 200-godišnjica sremske-iriške kuge, ur. Vojislav Jovanović (Novi Sad: Naučno društvo za istoriju zdravstvene kulture Vojvodine, 1996), 113.

${ }^{36}$ Sava Tekelija, Dnevnik, prir. Stevan Bugarski (Novi Sad: Matica srpska, 2011), 88.

${ }^{37}$ Radivoj Simonović, Kuga u Sremu: godine 1795-1796., prir. Živko Marković (Novi Sad; Irig: Srpska čitaonica; Budućnost, 1995), 46.

${ }^{38}$ Sveti Haralampije se u Irigu slavi kao zaštitnik od kuge, jer je na dan njegovog praznovanja, 10. veljače 1796. godine, konačno prestala kuga u Irigu. Maksimović, Srem u vreme kuge, 38-39. Međutim, štovanje svetog Haralampija kao zaštitnika od kuge rašireno je i među drugim pravoslavcima. Naime, Grci su na dan svetog Haralampija svetcu žrtvovali malu košulju koje su žene otkale i sašile tokom jedne noći, sve u cilju da se zaštite od kuge. Slobodan Zečević, Srpska etnomitologija, ur. Bojan Jovanovski i Božidar Zečević (Beograd: Službeni glasnik, 2008), 281.

39 Simonović, Kuga u Sremu, 45.

${ }^{40}$ Isto, 46.
} 
kozje noge i kozji papci na nogama. Na svakoj su ruki po četiri prsta, ni na jednom prstu nema nokata“ “. ${ }^{41}$ Uopćen opis kuge, koji se podudara s ranije navedenim, na južnoslavenskom prostoru predstavio je Edmund Schneeweis. Ona je redovito viđena kao ružna i stara žena ,s dugom kosom i dugim noktima, izbačenim zubima, obješenim grudima i stopalima jarca“". ${ }^{42}$

Teriomorfni opisi kuge podsjećaju na opise đavla koje su davale osobe optužene za vještičarenje tijekom XVIII. stoljeća na prostoru Slavonije. Između ostaloga, u iskazu čepinske ,vještice“ Anice Pauković, dobivenom mučenjem, đavao je bio u muškom liku, dok ,noge je imao kao jarac“ ${ }^{43} \mathrm{U}$ procesima protiv vještica vođenim u Slavoniji i Hrvatskoj tijekom XVIII. stoljeća, odnosno u njihovim iskazima, đavo je po pravilu prikazivan u muškom liku, dok kuga iz spomenutih opisa dolazi isključivo u ženskom liku, ali isto u teriomorfnom obliku. Već nam to ne dopušta jednostavno izjednačavanje kuge i đavla. No, ne treba olako odbaciti korelaciju između đavla i kuge, jer nerijetko se stara ružna žena predstavlja „kao ovaploćenje poroka i povlašćeni Sotonin saveznik“. Ipak, ostaje otvoreno pitanje u kakvom su oni odnosu.

Najprije treba znati da postoje barem dvije percepcije đavla; narodna i elitna, odnosno službena crkvena. To se može vidjeti, primjerice, u Lotaringiji i Juri, gdje je iz sudskih spisa ranog novog vijeka uočljivo nazivanje đavla, među narodom, običnim imenima, a ne biblijskim. ${ }^{44}$ Pored toga, izostavljeno je vezivanja đavla za karakterističnu crnu boju, već se on vezuju za zelenu, plavu ili žutu, ,što ih, kako izgleda, povezuje sa vrlo starim šumskim božanstvima Jura. Tako smo se našli u politeističkom univerzumu gde je đavo samo jedno božanstvo među inima drugima, koje se može laskanjem pridobiti i postati dobrotvorno". ${ }^{45}$

Đavao u poganstvu europskih naroda je nepoznanica, da bi u religiju tih naroda ušao preko kršćanstva. Pojedina božanstva, uglavnom ona visoko rangirana u panteonu poganskih naroda, postupno su sinkretizirana $\mathrm{u}$ formu kršćanskog đavla. Primjerice, to se dogodilo u slučaju germanskog Vodana. ${ }^{46}$ Nema sumnje da se taj proces morao dogoditi i Slavenima.

${ }^{41}$ Josip Lovretić, Otok - narodni život i običaji, ur. Manda Svirac (Vinkovci: Kulturno-informativni centar „Privlačica“, 1990), 554.

${ }^{42}$ Edmund Schneeweis, Vjerovanja i običaji Srba i Hrvata, prev. Dubravka Hrastovec (Zagreb: Golden marketing, 2005), 49.

${ }^{43}$ Vladimir Bayer, Ugovor s đavlom. Procesi protiv čarobnjaka u Evropi a napose u Hrvatskoj (Zagreb: Informator, 1982), 631.

${ }^{44}$ Delumeau, Strah na zapadu, 183.

${ }^{45}$ Isto, 183.

${ }^{46}$ Veselin Čajkanović, O vrhovnom bogu u staroj srpskoj religiji, ur. Vojislav Đurić (Beograd: Srpska književna zadruga; Beogradski izgavačko-grafički zavod; Prosveta; Partenon M.A.M., 1994), 123. 
Pišući o polapskim Slavenima, Helmold (XII. st.) govori o dobrom i zlom bogu, od kojih posljednjeg naziva Crnobogom i poistovjećuje s đavlom. ${ }^{47} \mathrm{Ve}-$ selin Čajkanović, na osnovi Helmodovog zapisa, došao je do zaključka da bi Crnobog definitivno bio bog iz slavenskog panteona i zbog epiteta crn odgovarao bogu podzemlja. Kasnije je Crnobog „deposendiran i iz različitih razloga izjednačen sa đavolom“, te je „mogao postati zao demon, ali prvobitno za njega nisu vezivane takve asocijacije“, već je on „najveći bog donjeg sveta, slovenski Dis pater“.48

S druge strane, i kuga ima nekoliko poveznica s donjim svijetom. Ne treba zaboraviti kako je redovito prikazana kao stara žena obučena u bijelo, a ta je boja u slavenskoj mitologiji bila izričito htonska. ${ }^{49}$ Treba spomenuti još i to kako se u Srijemu vjerovalo da kuga oko vrata nosi kesu u kojoj je bila knjiga $\mathrm{s}$ imenima svih onih koje treba da umori ${ }^{50}$ to jest ona je poslana da ispuni određenu sudbinu pojedinaca. Ovaj motiv asocira na kršćanskog arkanđela Mihaela, koji vadi dušu te je vodi na suđenje, da bi je poslije toga odveo u raj ili pakao. Nesumnjivo da je arkanđel Mihael zamijenio pandan iz poganstva. Zanimljivo je kako je u slavenskoj pretkršćanskoj religiji to „starac sede brade, odeven u belo, koji prema redu zapisanom u „božjem tefteru“ dolazi po duše i odvodi ih na drugi svet" ${ }^{51}$ što podsjeća na ranije spomenuti opis kuge.

Izravna poveznica đavla i kuge može se pronaći u vjerovanju zabilježenom u Slavoniji prve polovice XIX. stoljeća. Pučko vjerovanje govori o bogatom kralju koji dugo vremena nije mogao imati poroda, unatoč sedam brakova. Tek mu je zajednički život s osmom ženom podario potomke. Za tri godine života s njom izrodile su mu se tri kćeri, ali sve tri su rođene s kozjim nogama. Kada su kraljeve kćerke već bile odrasle „,njihova se mati ukaže kralju, da je vrag, i da je samo žensku osobu uzeo, da kralja napastuje“. 52 Saznavši ovo, kralj zatoči svoje kćeri. No, poslije dužeg vremena kraljeve kćeri oslobodi neki dvorjanik, misleći da su sakrivene zbog svoje ljepote. Nije prošlo mnogo vremena od bijega kraljevih kćeri kada „dobije kralj glas da mu kuga sve kraljevstvo opusti“".53

U ovoj priči iz Slavonije prepoznaju se pretkršćanski motivi, odnosno sličnost s antičkom mitologijom. Dvorjanik, poput radoznale Pandore, pušta

\footnotetext{
${ }^{47}$ Isto, 63.

${ }^{48}$ Isto, 67

${ }^{49}$ Zečević, Srpska etnomitologija, 127 i 399.

${ }^{50}$ Lovretić, Otok - narodni život i običaji, 554.

${ }^{51}$ Zečević, Srpska etnomitologija, 360.

${ }^{52}$ Luka Ilić Oriovčanin, Narodni slavonski običaji, ur. Željko Voborski (Novska: Gradsko poglavarstvo grada Novske, 1997), 299.

${ }^{53}$ Isto, 299.
} 
zatočene sestre na slobodu, nakon čega nedaće pogađaju kraljevstvo. U Pandorinom slučaju, nedaće je podvalio Zeus u kutiji (ćupu), dok je u slavonskom slučaju kuga rođena đavlovom obmanom kralja. No, najvažniji aspekt ove priče je činjenica da se kuga javlja kao kćer đavla, čime se direktno povezuje s bogom podzemlja. Ovo, uz ranije navedene podatke, kugu nesumnjivo svrstava među htonska bića slavenske mitologije.

Dakle, istovremeno imamo dva kontradiktorna vjerovanja o kugi, jedno kako je ona božja kazna, a drugo kako nju uzrokuju poganski demoni. U ovom dualizmu uočava se raskorak u kršćanstvu koje propagira crkva i kršćanstvu koje je zaživjelo u narodu. Premda je religioznost naroda po formi kršćanska, ona je ipak prošarana poganskim motivima koje kršćanstvo nikada nije u potpunosti istisnulo. Očito, u kršćanskom društvu Slavonije i Srijema XVIII. stoljeća i nije sve tako kršćansko.

\section{Duhovna briga svećenstva}

Bez obzira na to tumači li se epidemija kuge kao božja kazna ili demonsko djelo, molitvama, ispovijedanjem i na druge načine željelo se iskupiti pred Bogom ili pobijediti nečiste sile uz božju pomoć. Molilo se iz preventivnih i kurativnih razloga, odnosno kako bi ostali pošteđeni kuge ili kako bi epidemija bila okončana. Nekoliko svjedočanstava o duhovnoj brizi svećenstva za svoju pastvu, odnosno za spas od kuge, prikazano je na sljedećim stranicama.

Vukovarski prota Mojsije, slušajući naredbe iz mitropolije u Sremskim Karlovcima povodom pojave kuge u Srbiji i Bosni 1762. godine, zapovjedio je „da bi po svim crkvam u svojemu protopopijatu naredbu učinite vodosveštenije činiti i toju narodu kropiti, takođde priljeđno molesbstvovati, čto bi $\mathrm{B}(\mathrm{o}) \mathrm{g}$ prevednij gnjev svoj o(t) nas o(t)vratiti umilostivio se, tako vam ukazom njih visoko preosveštenstva i ekselen(cije) i pak naručujem po svima crkvami molebstvija da ne oskudevajut, s(vja)ščenikom naručite i sami o tom nastojte i molebstvovati narod uvješčavajte da molitvoju i pokajanijem umilostivljavajut $\mathrm{o}(\mathrm{t})$ pravednog svojeg gnjeva da prestanet". ${ }^{54}$

Mitrovački protoprezviter Isaković 1795. godine poručivao je svećenstvu: „koliko Vi sami, tako i Parohijani Vaša vozbuditi potščitesja, da bdjenija, molitvi, i molenija vseščedromu i Premilostivomu Tvorcu, s sokrušenim serdcem, koji životom i smertiju vladjejet Gospodu prinositi Jekteniju vo vremja

\footnotetext{
${ }_{54}$ Vladan Gavrilović „Podaci iz »Vukovarskog protokola« o sprečavanju prenošenja kuge u Srem 1762. godine“, u: Zbornik radova: Izvori o istoriji i kulturi Vojvodine, ur. Dejan Mikavica (Novi Sad: Filozofski fakultet Novi Sad, 2009), 157.
} 
gubitelstva ot predstatii naprasnija smerti, Apostol, Evangelije, tropar, kondak, tako po vsja dni ne izostavno tvoriti“".55

U cirkularnom pismu koje je poslao po pakračko-slavonskoj eparhiji episkop Kiril Živković savjetovao je kako od ,zaraznih bolesti mogu sebe sačuvati, uz to i iskrenom ispovesti i pokajanjem, i postom i molitvom sačuvaće Bog one koji od Gospoda pokroviteljstvo i milost prose, svojim nepostižnim promislom". .56

Pojava epidemije, svakodnevno suočavanje sa smrću i na kraju bespomoćnost reaktivirali su pobožnost naroda koji je tražio bilo kakvu slamku spasa. Kada je kuga pokazivala svoju snagu u Marseillesu prve polovice XVIII stoljeća, po pisanju La Gazette, je „oživeo religiozni žar“ ${ }^{57}$ Strah za vlastiti život bio je okidač buđenja religijskih poriva i u Srijemu. „A kad buna među ljude uđe, / I svakome smert pred oči dođe“, kako je zabilježeno u djelu $P e$ sma o slučaju bolesti iriške leta Gospodnjeg 1795 nepoznatog autora, ${ }^{58}$ „Tadaj se počeše svi Bogu moliti, / Niščim delit' i pravo tvoriti, / Brojanice počeše nositi" .59

Osim zazivanja božje pomoći, spas se tražio i u bilo kakvoj alternativi. Nepoznavanje djelotvorne liječničke metode, strah od zaraze i na koncu želja za životom, ljude su usmjeravali ka mogućim rješenjima. Usluge pružatelja nade bile su tražene. S negodovanjem pisao je Konstantin Stojšić ${ }^{60}$ da ,amajlije prave se i kojekakve travke, na primer otadeva i što znam kako se zovu, što nisam u životu čuo, za skupe novce traže se“ ${ }^{61}{ }^{61} \mathrm{Na}$ pogansko vjerovanje nužno se nadovezuju i poganske mjere obrane ili udovoljavanja kugi. Samo jedan od primjera je oboravanje naselja, zabilježeno 1739. godine u selima Požeštine. ${ }^{62}$ Dakako da su ovakve pojave nailazile na osudu svećenstva, kako pravoslavnog, tako i katoličkog.

${ }^{55}$ Krstić, „Okružnice sveštenstvu za vreme kuge u Sremu 1795 i 1796 godine“, 2.

${ }^{56}$ Milošević, Novaković, Novaković, „Propisi za borbu protiv kuge u Pakracu 1796. godine“, 200.

${ }^{57}$ Delumeau, Strah na zapadu, 105.

${ }^{58}$ Pjesma je vjerojatno nastala nakon epidemije kuge u Irigu. Ona je pronađena u ostavštini Vuka Stefanovića Karadžića u Arhivu Srpske akademije nauka i umetnosti.

${ }^{59}$ Bugarski, „Podaci o sremskoj kugi u zapisima Save Tekelije“, 35.

${ }^{60}$ U vrijeme epidemije kuge za Konstantina Stojšića zna se da je službovao kod mitropolita Stratimirovića i bio njegova osoba od povjerenja.

${ }^{61}$ Mikić, Kolarović, „Dva svedoka o Sremskoj kugi 1795-1796. godine“, 230. Vesna Ćosić navela je u predgovoru drugog izdanja Simonovićeve knjige kako su Irižani kugu nastojali otjerati krpenom lutkom kao kakvom amajlijom. Simonović, Kuga u Sremu, 5.

${ }^{62}$ Robert Skenderović, „Kuga u Požegi i Požeškoj kotlini 1739. godine“, Scrinia Slavonica 3 (2003), 169. Iriška kuga u sjećanjima Irižana ostala je i do suvremenog doba. Tako je 90-ih godina XX. stoljeća zabilježeno jedno zanimljivo predanje, koje možda ne bi trebali olako 


\section{Uloga svećenstva kao posrednika na relaciji država-narod}

Mnogi su smatrali da je bježanje iz područja zaraženog kugom jedini mogući spas, dok su drugi bili uvjereni kako ne postoji spas pred sudbinom. Pored toga, svi ,zajedno suprotstavljali su se svakoj javnoj mjeri, pa su tako bili i protiv granica koje je odredila vlast, kao i protiv donetih naredbi i propisa" " ${ }^{63}$ kako je zaključio Franz von Schraud, rukovodeći liječnik u suzbijanju kuge u Srijemu tijekom 1795/96. godine. Isti problem prepoznao je i pravoslavni mitropolit Stefan Stratimirović, smatrajući kako „kuga neprestaje, no rasprostranjava se; sve se to pripisuje neposlušaniju naroda ko zapovjedem ot vlasti davajemim, i sujevernim gogože naroda običajem, čto neće ti ljudi Doktore da slušaju, no ot priimanja ljekarstva gnušaju se" ${ }^{64}$

Mogli bismo se zapitati kakvo su mišljenje imali oni zatočeni unutar sanitarnog kordona koji je čuvala vojska i pod prijetnjom života branila izlazak iz njega. Obruč oko žarišta smrti osuđivao je pojedinca na svakodnevno suočavanje s vrlo izglednom vlastitom budućnosti. Dakako, ni donesene sanitarne mjere i liječničke metode nisu pružale utjehu onima u kordonu. Učinkovitost sanitarnog kordona nije odmah bila vidljiva, a onima unutar njega možda ni pretjerano bitna, jer oni su tamo gdje epidemija vlada. Same mjere prvenstveno su bile usmjerene na ograničavanje zaraze, dok metode liječenja zaraženih nisu bile djelotvorne. Doživljavani kao osuđenici na smrt, nisu mogli biti povjerljivi prema sanitarnim mjerama, čiji se učinak nije jasno ispoljavao, kao ni prema onima koji su ih donosili. Prezir i nepovjerenje prema stranim liječnicima nisu mogli olako biti uklonjeni.

Pored toga, provođenje sanitarnih mjera nužno je zahtijevalo ukidanje do tada ustaljenih običajnih praksi, naročito po pitanju pogrebnih običaja. Dolazi do onoga što je Jean Delumeau nazvao ukidanjem personalizirane smrti. ${ }^{65}$ „Suze, tiho šaputanje, prizivanje uspomena, polaganje u mrtvački sanduk, molitve, pogrebna povorka, prisustvo rodbine i prijatelja: sve su to sastavni

odbaciti. Naime, Irižanin Predrag Simić ispričao je lokalnu legendu kako su Irižani u potrazi za spasom od kuge žrtvovali jednu djevojčicu te je živu zakopali negdje na današnjem potezu Gajevi. Vjerodostojnost legende potkrepljuje se još podacima da su danas oko toga mjesta česte prometne nesreće, kao posljedica pojave fatamorgane. Nesreće će se, po predanju, događati dok na tom mjestu ne poginu tri jedinca ili dok se ne prinese primjerena zamjenska žrtva. Marković, „Irižani o kugi““, 112. Možemo li u toj priči prepoznati ostatke poganstva u vidu krvne žrtve?

${ }^{63}$ Franz von Schraud, Istorija kuge u Sremu: 1795-1796, prev. Jovan Valrabenštajn (Novi Sad: Naučno društvo za istoriju zdravstvene kulture Vojvodine, 1995), 24.

${ }^{64}$ Krstić, „Okružnice sveštenstvu za vreme kuge u Sremu 1795 i 1796 godine“, 20.

${ }^{65}$ Delumeau, Strah na zapadu, 89. 
delovi jednog obreda prelaska koje se mora odvijati kako božji zakon i ljudski sram nalažu“". ${ }^{66}$ Sada je sve moralo biti izostavljeno.

Postupak odvajanja zaraženih i sumnjivih od zdravih izazivao je nezadovoljstvo te je ponekad tumačen kao djelovanje protiv lokalnog stanovništva. Tako se među pravoslavnim stanovništvom Vukovara razvio stav kako „u sve to treba sumnjati, pošto se kuga pojavila samo među pravoslavnim stanovništvom. I ovde je zadržano pravo da se posumnja u versku mržnju“ ${ }^{67}$ Već napeta situacija prouzrokovana povećanim mortalitetom dodatno je zakomplicirana tumačenjem vjerske netrpeljivosti, što je lako moglo eskalirati u pobunu pravoslavaca. Do odbacivanja ovog mišljenja došlo je tek kada se stjecajem okolnosti kugom zarazila i jedna katolička obitelj.

Kako bi se stanovništvo ponašalo u skladu s propisanim sanitarnim mjerama, bilo je nužno naći posrednika na relaciji država-narod, a u kojeg stanovništvo ima povjerenje. Uz sve dobre namjere, to nisu mogli biti strani liječnici, koje narod nije poznavao i prema njima je gajio odbojnost. Shodno tome, državni ograni su posrednika u provođenju sanitarnih mjera pronašli u lokalnom svećenstvu.

Već iz slučajeva iz vremena tzv. erdeljske kuge uočljivo je kako je stanovništvo nerijetko bilo sklonije svome svećenstvu nego državnoj zdravstvenoj službi. Primjerice, u Slankamenu, tijekom tzv. erdeljske kuge, stanovnici nisu čistili kuće propisanim postupkom, već su (umjesto prskanja octom i dimljenja) skloniji bili dovođenju i plaćanju svećenika koji bi ih blagoslivljao svetom vodom i u njima čitao molitve. ${ }^{68}$

Uvažavanje koje je svećenstvo imalo među narodom Srijema uočio je i Franz von Schraud, zbog čega je zaključio kako bi bilo dobro imati na svojoj strani svećenike „čiji su primer Sremci rado sledili““ ${ }^{69}$ Istoga je bio svjestan pravoslavni mitropolit Stefan Stratimirović, znajući kakvu ulogu u suzbijanju kuge može imati svećenstvo. On je čak prebacivao odgovornost za opstojnost kuge $\mathrm{u}$ istočnom Srijemu tijekom tzv. iriške kuge na svećenstvo koje bi moglo svojim trudom ubrzati akciju suzbijanja zaraze. „Kada bi govorim ovo njima ot Svjaštenstva neprestano u pamet metato, i na sovjest i dušu, da ne bi sebe sa svim pogubili nalagano, to bi zaista kuga do sada istrebiti se mogla. Imam živii primjer u Karlovci i u Vukovaru gdi se također ovo zlo uselilo bilo, i za verlo kratko vreme črez to što su ljudi uredbama onima, koje je vlast tvorila pokoravali, ljekarstva upotrebljavali, i sa svim život svoj onako vodili, kako što je im zapovjedano, a sve ovo črez neprestanoje Parohijalnih Svjaštenikov

\footnotetext{
${ }^{66}$ Isto, 89.

${ }^{67}$ Schraud, Istorija kuge u Sremu: 1795-1796, 64.

${ }^{68}$ Slavko Gavrilović, Srem od kraja XVII do sredine XVIII veka (Novi Sad: Filozofski fakultet u Novom Sadu, Institut za istoriju, 1979), 254.

${ }^{69}$ Schraud, Istorija kuge u Sremu: 1795-1796, 34.
} 
uvještanije i nastavlenije točno tvorili jesu; i tako budi blagodarenije Bogu! Sa svim sebe ot ove tuge oslobodili jesu. “70

Grgeteški arhimandrit Stefan Avakumović je u nedatiranom pismu, ali s početka epidemije, svećenstvu naglašavao da je njihova dužnost „da Vi o nuždje i polzje sego visokago ureždenija, ježe tokmo za sije vremja nuždi trajati imjejet, narod uvjerite, i taj nalog bez vsjakago roptanija ispolnjavati blagorazumnim nastavlenijem poučite i sovjetujete...".71

U pismu datiranom 19. rujna 1795. godine (po julijanskom kalendaru) arhimandrit Avakumović naglašavao je: „Ašče bi gdje obstojatelstva iziskivala i zato Cerkov zatvorila bisja protivu takovago i drugago obstojatelstvam sam priličestnujuščago ureždenija ne roptati no vsjakii političeskii nalog jako Bogom postavlenoju vlastiju danii; ibo niktože priimiv vlast razvje ot Boga, i jako za sije opasnoje vremja nužnoe i poleznoe, i samomu Bogu povolnoje upreždenije priznati." "72 Dakle, bilo je važno naglasiti kako svjetovna vlast nije oprečna Bogu, odnosno kako sanitarne mjere koje ona propisuje nisu uperene protiv Boga, već da su one po božjoj volji. Četiri dana kasnije mitrovački protoprozviter Isaković nadležnom svećenstvu je prenosio arhimandritove riječi, upućujući svećenstvo: „narod sovjetujte i nastavite da sve vozmožno v sije nuždnoje vremja visoka naredba naroda radi o soderžanii nihovog dobrago zdravija tvorit, tako da narod ovomu visokomu ureždeniju za radi ih tvorimomu pokornost sotvoriti potštitsja, i do tolje trajati budet, do nelježe gnjev Božiji ot nas dvignetsja i ova bolest prestanet, a da ovo učreždenije ni zakonu ni Cerkvi najmanje protivno stojit“. ${ }^{73}$ Protoprezviter Isaković je i početkom listopada 1796. godine svećenstvo upućivao da narod savjetuje „u Cerkvi, vnje Cerkve, i u svakom razgovoru i priliki, da na stražama bodro čuvaju koga propustiti, ili iz kužna mjesta čto taino uzeti, ili čto v domje svojem takovo zatajiti, a osobito u ovakom slučaju vlasti zemaljskoj povinovatisja i čto oni nareždujut tščalivo i bodro ispoljnjavati, ibo na takovoga prestupnika ot jedinom ili drugom gnjev Božiji, Anatema svjate Cerkve, i strašnago Suda Božija, izgubljenje Carstva nebesnago sljedujet" ${ }^{\text {" }}{ }^{74}$

Relacija država-svećenstvo-narod možda se najbolje vidi kroz naredbu načelnika rumskog kotara, koji je kolovoza 1797. godine, na glas o kugi u Osmanskom Carstvu, zapovjedio određene mjere te da se iste „kroz sveshte-

\footnotetext{
${ }^{70}$ Krstić, „Okružnice sveštenstvu za vreme kuge u Sremu 1795 i 1796 godine“, 20.

${ }^{71}$ Isto, 3.

${ }^{72}$ Isto, 8.

${ }^{73}$ Isto, 5.

${ }^{74}$ Isto, 8.
} 
nika u czerkvi naznanje imadu dati“ “ ${ }^{75}$ Prema tome, nije pogrešno u riječima predstavnika crkve prepoznati projekciju riječi svjetovnih vlasti, odnosno doživjeti crkvena lica kao transmiter u prijenosu informacija.

S druge strane, nameće se pitanje uspješnosti relacije država-svećenstvonarod. Iako je mitropolit Stefan Stratimirović zaključio kako nije „naš rod tako glup i uporan da ne bi Svjaštenstvo poslušao" ${ }^{76}$ čitatelj bi se ipak s pravom zapitao koliki je bio stvarni utjecaj svećenstva. Naime, kroz spomenute primjere vidimo da se isti problem, to jest potreba za savjetovanjem lokalnog stanovništva da se ne treba odupirati sanitarnim mjerama, stalno javlja. Ta poruka bila je često praćena prijetnjom isključivanja iz Crkve, Božjim sudom i općenito zastrašivanjem, te je kao takva trebala izazvati kod vjernika pokornost. Ponavljanje identičnih naredbi, poput zabrane cjelivanja pokojnika i drugih, navodi na zaključak kako određene običajne radnje nisu mogle biti olako iskorijenjene ni posredstvom svećenstva.

Pored toga, dalo bi se zaključiti i to da komunikacija između nadležnih u suzbijanju kuge i svećenstva nije bila dovoljno jasna. Primjerice, liječnik Hass morao je 1795. godine u Jasku zabraniti svako javno bogosluženje, ,jer se verovalo da se ona mogu držati na ulici ako je to u crkvi zabranjeno".77 Ipak, iz drugih svjedočanstava vidimo da je vjerovanje svećenstva i naroda kako se mise mogu držati na otvorenom bilo opravdano. To je izričito naređivao arhimandrit Stefan Avakumović u jednoj sačuvanoj okružnici svećenstvu, navodeći crkve „do dalšago ureždenija zatvoriti, i svjaštennosluženije tokmo pod šatorom na svobodnom polju narodu soveršivati““. ${ }^{78}$ Arhimandritove riječi ipak nisu bile protivne zapovijedima svjetovnih vlasti, što svjedoči naredba načelnika rumskog kotara Lovrenčića: „sluxbe Bozie dase ne csine, vech napolje kako schto jeste vech curentirato, jedan od drugoga nekase csuvaju izmedyu sobom niti nablizu dasze sastaju“ “ ${ }^{79}$

\section{Svećenstvo i provođenje sanitarnih mjera}

Izvanredno stanje nastalo kao posljedica epidemije kuge drastično je promijenilo životne navike stanovništva na okuženom području. Promjena nisu

\footnotetext{
${ }^{75}$ Vasa Krstić, „Naredbe načelnika Rumskog sreza za vreme kuge u Sremu 1795-1796 godine“, u: Prilozi za istoriju zdravstvene kulture Jugoslavije i Balkanskog poluostrva (Beograd: Biblioteka Centralnog higijenskog zavoda, 1940), 9.

${ }^{76}$ Krstić, „Okružnice sveštenstvu za vreme kuge u Sremu 1795 i 1796 godine“, 22.

${ }^{77}$ Schraud, Istorija kuge u Sremu: 1795-1796, 55.

${ }^{78}$ Krstić, „Okružnice sveštenstvu za vreme kuge u Sremu 1795 i 1796 godine“, 3.

${ }^{79}$ Krstić, „Naredbe načelnika Rumskog sreza za vreme kuge u Sremu 1795-1796 godine“, 6.
} 
ostale pošteđene ni religijske navike stanovništva, zbog čega se i samo svećenstvo moralo prilagođavati izvanrednim okolnostima.

Još tijekom epidemije kuge u Bosni i Srbiji 1762. godine iz tzv. Vukovarskog protokola možemo uočiti aktivnu ulogu svećenstva u provođenju sanitarnih mjera. Naime, vukovarski prota Mojsije, dobivši pismo Jeftimija Radosavljevića iz Sremskih Karlovaca, odgovara: „Kako se ta kužna boljezi javila u komšiluku ostri cirkular na protopope i popove opravite, da se dobro čuvajut s ljudima one strane ne sastajati se ili kakoje hespape kupovati, ili koga god bez osvjedetelstvovanija izderžate kontromacije ili voinstvenago propuska k sebje na razgovor ili na konak, ili ot veščej kakovih god na ostavu ne primati i slovom sebe i svoje o(t) svakog pomješatelstva hraniti da ne uniđete u nesrećju, a takovo čto slučitsja, znajte da i života kasajetsja“ ${ }^{60}$ Tom prilikom svećenstvu je naređeno još ,nepogrebavati umirajuđčago dokle felčeri umeršago ne vizitirajut, s(vja)štenici da ne derzajut prežde pregledanija pogrebavati i u crkvu unositi mertveca da se gdjegod ne bi priključilo kako prežde u Čalmi“".81

Mitrovački protoprezviter Isaković savjetovao je početkom epidemije kuge u Srijemu 1795. godine svećenstvo: ako bi tko od njihovih parohijana obolio, „takovomu vo pervih postarajte se feldčera privesti, i po polućeniju ot togo cjeduli dozvolenija, k takovomu bolesniku otiti možete" . 82 No, ako se „strahotnoi smertnoi boljezni pojaviti, Vi tamo niti prihodite opojati, niti zvonami oglasiti““. ${ }^{83} \mathrm{U}$ pismu iz kolovoza 1795. godine arhimandrit Stefan Avakumović je naređivao svećenstvu da ne posjećuje bolesnike dok se ne dobije „pismenoje dozvolenije ot Gdina Solgabirova““ ${ }^{84}$ Tek po dobijanju dozvole svećenici su morali s oprezom pristupati bolesniku te ,na tri koraklja ot nego otstojašče ispovjedite, i svjatuju tainu s kašičicom drvenom na dugačkom drvetu prevezanom podaite, a jegde takovago prečestite, drvo i kašiku abije spaliti sotvorite“ ${ }^{85}$

Arhimandrit Avakumović je u pismu s početka epidemije srijemskom svećenstvu iz 1795. godine naredio da se „Mertvaja tjelesa ravnje že do dalšega ureždenija dati zakovati, i tako ne v Cerkov, no upravo u grobije bez raznstvija otnositi, i ot njud nikomu mertvoje tjelo cjelivati dozvoliti““ ${ }^{86}$ Kolovoza

\footnotetext{
${ }^{80}$ Gavrilović, „Podaci iz »Vukovarskog protokola« o sprečavanju prenošenja kuge u Srem 1762. godine", 155 .

${ }^{81}$ Isto, 157.

${ }^{82}$ Krstić, „Okružnice sveštenstvu za vreme kuge u Sremu 1795 i 1796 godine“, 2.

${ }^{83}$ Isto, 2.

${ }^{84}$ Isto, 4.

${ }^{85}$ Isto, 4. Ista praksa zabilježena je diljem Europe (Delumeau, Strah na zapadu, 83).

${ }^{86}$ Krstić, „Okružnice sveštenstvu za vreme kuge u Sremu 1795 i 1796 godine“, 3.
} 
1795. godine arhimandrit ovo je nadopunio time da se „ni tjelo takovoje mertvoje do grobija provoditi i opojavati““ ${ }^{87}$ Ipak, Franz von Schraud je zabilježio kako se nije „moglo sprečiti da se umrli u kući sahranjuju sa svom uobičajenom pompom". ${ }^{88}$ I dalje se događalo okupljanje mnoštva rodbine te susjedstva nakon pogreba na dvodnevnu ili trodnevnu daću, koja je pravljena u kući domaćina, a „bogata trpeza i darežljivost domaćina namamljuje i veliki broj siromaha" ${ }^{89}$ Kako spomenute naredbe nisu zaživjele, još siječnja 1796. godine arhimandrit Avakumović pisao je rumskom namjesniku povodom obrednih običaja koji su se provodili po ustaljenoj navici, suprotno traženju Sanitarne komisije. Stoga je on namjesniku naredio da se sanitarni propisi poštuju i da se narod savjetuje pod prijetnjom lišavanja čina nemarnog svećenstva. ${ }^{90}$

Međutim, već spomenuta Pesma o slučaju bolesti iriške leta Gospodnjeg 1795 ukazuje kako je ipak došlo do određene promjene u do tada uobičajenim pogrebnim običajima. Očaj i bespomoćnost, kao i izostanak pogrebnih običaja, jasno su izraženi u stihovima: ,„.. a grobari tud s koli prolaze, / pak tovare gdi god kog nalaze, / sve zajedno mertve i bolesne, / ne žali ga, s njim o lesu tresne, / nit se štedi bogat ni siroma, / sve gomilom dovode do groba, / bez opela i zvonoglašenja, / i parade, popovska pratenja, / bez kićenja i cerni frolova, / i kupenja ostali rodova!".91

Kako bi se izbjeglo daljnje širenje zarazne bolesti, bilo je nužno onemogućiti bilo kakav kontakt između zaraženih i zdravih, zbog čega su zabranjena

${ }^{87}$ Isto, 4.

${ }^{88}$ Schraud, Istorija kuge u Sremu: 1795-1796, 24.

${ }^{89}$ Isto, 54.

${ }^{90}$ Krstić, „Okružnice sveštenstvu za vreme kuge u Sremu 1795 i 1796 godine“, 22-23. Po pitanju pogrebnih običaja i provedbe sanitarnih mjera, pravoslavna crkva imala je već ranije problema. Kada je 1756. godine Ugarsko kraljevsko namjesničko vijeće donijelo naredbu da se odrede kirurzi koji će biti zaduženi za pregled mrtvih te da svećenici ne smiju nikoga sahraniti bez potvrde da je tijelo pregledano započela je s radom institucija mrtvozornika. Slavko Jovin, „Uvođenje nadzora nad umrlima na teritoriji Vojvodine i stav Srpske pravoslavne Crkve", Acta historica medicinae, pharmaciae, veterinae 20 (1980), br. 1/2, 201. Međutim, provedba ove naredbe nailazila je na otpor među pravoslavnim stanovništvom. Tako se magistrat Novog Sada žalio veljače 1757. godine kako se pravoslavci i njihovo svećenstvo opiru provođenju ove naredbe. Shodno tome, Slavko Jovin zaključuje kako je „verovatno da je niže sveštenstvo i prosti narod, nepoverljiv prema svemu što je dolazilo od vlasti a zadiralo u njegovu nacionalnu i versku tradiciju sa rezervom, možda i neprijateljski gledao na ovu novinu i davao otpor" (Isto, 202). Izgleda da ova pojava nije bila prisutna samo među bačkim pravoslavcima, već i na ostalim prostorima gdje je bio naseljen pravoslavni narod. Tako je mitropolit Pavle Nenadović, pišući episkopu budimskom Dionisiju Novakoviću rujna 1757. godine, naveo „da su neki među pravoslavnima, sa raznih strana, odbili da se povinuju ovoj carskoj naredbi, meni je zato rastriktom od 18. juna ove godine milostivo naloženo da na nadležna mesta pošaljem naredbu o tome, o čemu je i na prošlom ovogodišnjem Sinodu bilo reči i zaključeno da se gospoda episkupi o tome cirkularno izveste" (Isto, 202).

${ }^{91}$ Maksimović, Srem u vreme kuge, 35. 
javna okupljanja. U tom cilju, još kolovoza 1795. godine načelnik rumskog kotara Lovrenčić naređivao je da se mise ne čine u crkvama, već napolju, uz sigurno rastojanje među vjernicima. Istu naredbu pronalazimo u pismu arhimandrita Avakumovića srijemskom svećenstvu, gdje se navodi kako se služba treba održavati ,pod šatorom na svobodnom polju“ “. ${ }^{92}$ Odraz tih naredbi pronalazimo i u šarengradskom franjevačkom samostanu, gdje ,puk nije ulazio u Crkvu kroz 20 dana. Ništa se kod nas nije pokazalo od zarazne bolesti““.93

Nekoliko mjeseci kasnije, studenoga 1795. godine arhimandrit Avakumović ukazivao je svećenstvu da je ,sastanak ljudski velikii i glavnii uzrok jest ninješne otrovne bolesti, zato slavnaja Sanitets Komisia za dobro i polezno obrjela jest, da za sadašnjeje vreme i u cerkvi ljudi ne sastajuse, i zato da crkve so svjem zatvorene budut" ${ }^{94}$ Međutim, iako su hramovi bili zatvoreni za javnost, svećenstvu je upućivano kako „možet v Cerkvje zatvorennoi Svjaštennosluženije soveršavati, a narod vsjakii pri svojem domu da budet, i jegda zvono uslišit člen svjatija liturgii oglašavajuščeje, vsjak v svojem domje sa svojom familiom Bogu molitisja i Blagogovjeistovati možet". ${ }^{95}$ Ta naredba važila je još lipnja 1796. godine, barem djelomično. „U meszta zdravi, gdi kuga nie morila, ove ni lanske godine dopuhsteno jeste ljudma u czerkvu ichi, toga radi Schatrinczem, Gergeteku, i Kruhsedollu Pernjavoru zabranjujese joss sada czerkovu otvoriti““. ${ }^{96}$

Poslije slučaja zaraze velikog broja ljudi u Velikim Radincima 1795. godine svećenicima je naređeno da „nepokustisja Svjatago objedom slaviti, ješče menše kolača takovome svečaru sješči, i pri njemu objedovati, ili daće deržati, i k takovim daćama, Vi na objed otlaziti ne usudilibisja, pod lišenijem čina i Parohii“. ${ }^{97}$ Ako bi se tko od „Paroh, Supernumerarni Svjaščenik Diakon ili koji ot klera da bi sja pokusil ne samo takove Gozdbe i skupštine nezabraniti, no ješče derznul bi sam takovim prisudstvovati, takovago Ja bez dalšija naredbi hoću pod otlučenije Parohii i Svjaščennosluženija podvergnuti, a potom visokim mjestama, i Jego Eksellenciji našemu Gdinu Arhi Episkopu, za takovago prestupnika degradaciju nižajšeje moje predloženije učiniti“'.98 Zabrana potencijalnih okupljanja još je jednom ponovljena u cirkularnom pismu mitrovačkog protopresvitera Isakovića iz studenoga 1795. godine, gdje

\footnotetext{
${ }_{92}$ Krstić, „Okružnice sveštenstvu za vreme kuge u Sremu 1795 i 1796 godine“, 3.

${ }^{93}$ Budimir Cvitković, ur., Ljetopis franjevačkog samostana $u$ Šarengradu (Šarengrad: Franjevački samostan Šarengrad, 2002), 147.

${ }^{94}$ Krstić, „Okružnice sveštenstvu za vreme kuge u Sremu 1795 i 1796 godine“, 11.

${ }^{95}$ Isto, 11.

${ }^{96}$ Krstić, „Naredbe načelnika Rumskog sreza za vreme kuge u Sremu 1795-1796 godine“, 8.

${ }^{97}$ Krstić, „Okružnice sveštenstvu za vreme kuge u Sremu 1795 i 1796 godine“, 9.

${ }_{98}$ Isto, 9.
} 
se svećenstvu u njegovoj nadležnosti naređuje „da slave Svečarske, Daće, i mnogoljudne svadbe prestanut, pri svadbama tokmo tri potrebite persone bez svirjelei s jednimručkom da bivajut, i to komu nužno bračitsja“.99

Ne malu ulogu svećenstvo je među narodom moglo ostaviti vlastitim primjerom. Poštivanje sanitarnih mjera od samog svećenstva davalo je stanovništvu zoran primjer kako one i jesu svrsishodne. Tako je i arhimandrit Avakumović naglašavao prosinca 1795 . godine rumskom namjesniku da svećenici moraju biti primjer uzornog ponašanja, zbog čega se žali što „Svjaštennici ot mjesta do mjesta hodjat i takovim načinom protivni primjer narodu dajut" .100 Stoga je on rumskom namjesniku naredio da nitko od svećenika ne smije napuštati pojedino mjesto, osim u slučaju krajnje nužde. I mjesec dana ranije arhimandrit Avakumović ukazivao je na loš primjer svećenstva. Naime, paroh velikoradinački Jakov Mirković nije se ponašao u skladu s naredbama te je i svoje parohijane na isto navodio, zbog čega će završiti na sudu političkih vlasti. ${ }^{101}$ Neprimjerenom ponašanju svećenstva nije prijetila samo kazna svjetovnih vlasti, već je nerijetko za nepoštivanje sanitarnih mjera, odnosno oglušivanje o naredbu nadređenog svećenstva, mogla uslijediti i kazna lišavanja čina i parohije, što je redovito naglašavano u upućivanim okružnicama.

\section{Svećenstvo i medicinska služba}

Prolazeći 70-ih godina XVIII. stoljeća kroz Slavoniju i Srijem, Wilhelm von Taube zaključio je kako „Slavonija (i Srijem, op. a.) je Kraljevina bez ubožnica i bolnica, bez staračkih domova i lazareta, bez popravnih domova i umobolnica, bez gostionica, bez siročadskih domova, bez primalja, bez ustanova za gašenje požara, ukratko bez svega onoga što makar jedno osrednje redarstvo prvo uvodi kao neophodne i nužne stvari“. ${ }^{102}$

Riječi spomenutog putopisca druge polovice XVIII. stoljeća ne mogu se u potpunosti prihvatiti kao odraz stvarnog stanja; međutim, one ipak ukazuju na nedostatak liječnika i medicinskih institucija u Slavoniji i Srijemu. Prekretnica u razvoju medicine na slavonsko-srijemskom prostoru bila je odredba Marije Terezije iz 1766. godine da svako kraljevstvo, županija, distrikt i grad moraju imati zaposlene školovane liječnike. Dakako, ta odluka nije preko noći promijenila postojeće stanje. Nedostatak novca, kao i obrazovanih liječnika,

\footnotetext{
${ }^{99}$ Isto, 13.

${ }^{100}$ Isto, 19.

${ }^{101}$ Isto, 16.

${ }^{102}$ Freiderich Wilhelm von Taube, Povijesni i zemljopisni opis Kraljevine Slavonije $i$ Vojvodstva Srijema, ur. Stjepan Sršan (Osijek: Državni arhiv u Osijeku; Udruga povjesničara Slavonije i Baranje, 2012), 131.
} 
nisu omogućavali brzo provođenje te odluke, no ovime je udaren put ka unapređivanju zdravstva. ${ }^{103}$ Unatoč zdravstvenim reformama, nedostatak osoba s medicinskom izobrazbom i dalje je bio prisutan. Primjerice, u popisu obrtnika Požeške županije iz 1773. godine zabilježena su svega tri kirurga-obrtnika, dok je majstorski zanat učio jedan kalfa. Kako je tada Požeška županija imala populaciju od preko 60.000 ljudi, znači da je na čak 20.000 ljudi bio tek jedan kirurg. ${ }^{104}$

Međutim, prve polovice XVIII. stoljeća državnih ustanova i liječnika nije bilo ni približno kao druge polovice istog stoljeća, a ni sama medicinska znanost se još uvijek nije dovoljno dobro afirmirala. Nedostatak medicinskog osoblja na neki je način nadomjestilo svećenstvo, odnosno crkveni redovi koji su imali medicinsko obrazovanje ili iskustvo. S pravom je Wilhelm von Taube zaključio kako se redovnici „brinu kako za duše tako i za tijelo stanovnika mjesta i susjednih sela, budući da su oni ujedno i župnici, ljekarnici i liječnici“105 jer na slavonskom području nema medicinskog osoblja.

Gotovo da nije bilo samostana u Slavoniji i Srijemu koji na neki način nije pružao medicinske ili ljekarničke usluge. Važan medicinski centar bio je franjevački samostan u Virovitici. U njemu je od 1735. godine djelovao fra Bonifacije Gerber, koji je pored ranarničkog posla vodio i samostansku ljekarnu. Ta samostanska ljekarna je 1748. godine od Virovitičke županije počela dobivati pomoć od 60 forinti jer, kako je obrazloženo, na području čitave Virovitičke županije, od Osijeka do Koprivnice nema niti jednog drugog liječnika ni ljekarnice. ${ }^{106}$

No, što je s pravoslavnim svećenstvom? Za razliku od katoličkih redovnika, pravoslavni, izgleda, nisu imali toliko raširenu medicinsku djelatnost. ${ }^{107}$ Iako među pravoslavnim svećenstvom nije bilo toliko brojnih osoba s medicinskim predznanjem, pravoslavci su imali naviku, kako je uvidio Franz Stefan Engel, da „svoje bolesne rođake vode na nekoliko nedelja u kaluđerske manastire škodi ne samo domaćim prilikama nego i telu, jer, s jedne strane,

${ }^{103}$ Robert Skenderović, „Zdravstvene reforme Marije Terezije u slavonskom Provincijalu i Generale normativum sanitatis iz 1770.“, Scrinia Slavonica 5 (2005), 130.

104 Isto, 120.

105 Taube, Povijesni i zemljopisni opis Kraljevine Slavonije i Vojvodstva Srijema, 168.

106 Skenderović, „Zdravstvene reforme“, 117.

107 Općenito, nekatolici se nisu mogli školovati na medicinskim fakultetima unutar Dunavske Monarhije, već su u potrazi za obrazovanjem morali napuštati njene granice. Kasnije, 1771. godine, čak je i to onemogućeno, čime je nekatolicima uskraćeno pravo na studiranje. Tek dva desetljeća kasnije Josip II. omogućio je pristup svim građanima na fakultete Monarhije. Slavko Jovin, Istorija medicine i zdravstvene kulture na tlu današnje Vojvodine 1718-1849 (Novi Sad: Matica srpska, 1998), 69-70. Dakako, to je moralo za posljedicu imati da među pravoslavcima ne nalazimo istaknute liječnike svećenike. 
takav čovek, u vreme kada bi mu lekar još mogao da pomogne, pada u krajnji stepen bolesti i umre". 108

Ipak, pojedinci su dosegli određene medicinske vještine. Jedan od njih je svakako i Kiril Živković, koji je medicinsko znanje, navodno, stekao u bolnici kralja Milutina u Carigradu. Episkop Živković posebice je zanimljiv jer je u cirkularnom pismu s početka 1796. godine poslanom po svojoj pakračkoslavonskoj eparhiji savjetovao kako prepoznati kugu i kako se sačuvati od nje. Kirilovo pismo ima četiri tematske cjeline. Prva je naslovljena Predznaci kuge, druga Predohrana od kuge, treća Lekarstva od kuge, te četvrta Koliko vremena se kuga zadržava. Treba imati na umu kako su episkopove riječi onodobna shvaćanja kuge temeljena na zapažanju, odnosno iskustvenom učenju. ${ }^{109}$

Doprinos pravoslavnog svećenstva medicinskoj djelatnosti u vrijeme epidemija kuge ne ogleda se u njihovim medicinskim vještinama, već u podršci provođenju istih. Naime, pravoslavno svećenstvo predstavljalo je važnu kariku u tom lancu prijenosa informacija. Primjerice, smatrajući da bi narod u okuženom području radi strogosti posta „ne samo sebe izmožditi i za trud i posao nesposobne učiniti, no i u druguju kakovuju bolest pasti“" ${ }^{110}$ mitropolit Stefan Stratimirović je ožujka 1796. godine stanovništvo na epidemičnom području „obične strogosti posta osvobodili, i im mersnaja jastija uživati dozvolili““. ${ }^{111}$ Za pretpostaviti je kako je mitropolitova uputa uslijedila poslije neuspješnih apela sanitarnog osoblja. Mitropolit naglašava kako se u ovoj izvanrednoj situaciji može, odnosno mora odstupiti od uobičajene strogosti posne prehrane, ali uz supstituciju molitvama. Kao i u nizu ranije spomenutih primjera, i ovdje se ispoljava relacija država-svećenici-narod, odnosno mitropolitove riječi prenose poruku sanitarnog osoblja iscrpljenom narodu.

Zbog svoje revnosti u provođenju sanitarnih mjera, odnosno u nadzoru nad njima, pojedini svećenici su i nagrađeni. Takav je slučaj vukovarskog prote Ignjatija Mihajlovića, koji je, kako se vidi iz crkvenog računa iz 1797. godine, dobio od crkvene općine 150 forinti nagrade ,za otlikovanuju jego u vreme kužno i stadu svojemu službu“". ${ }^{112}$

${ }^{108}$ Franz Stefan Engel, Opis Kraljevine Slavonije i Vojvodstva Srema, ur. Slavko Gavrilović (Novi Sad: Matica srpska, 2003), 107.

109 Milošević, Novaković, Novaković, „Propisi za borbu protiv kuge u Pakracu 1796. godine“, 203. Cjelokupno episkopovo pismo prikazano je u radu ovih autora.

${ }^{110}$ Krstić, „Okružnice sveštenstvu za vreme kuge u Sremu 1795 i 1796 godine“, 23.

111 Isto, 23.

112 Jovan Kozobarić, Spomenica Srpske pravoslavne crkve u Vukovaru - prigodom proslave dvesta godišnjice, ur. Čedomir Višnjić (Zagreb: Srpsko kulturno društvo Prosvjeta, 2001), 44. 
Međutim, zalaganje koje je svećenstvo pokazivalo u vrijeme epidemija kuge imalo je svoju cijenu. Katoličko svećenstvo, točnije redovnici, preuzimali su skrb o oboljelima, dok su pojedini čak i boravili u bolnicama, ${ }^{113} \mathrm{zbog}$ čega su bili pod stalnim rizikom gubitka života. Stoga ne čudi da su se zemunski kapucini žalili 1743. godine: „u bolnicama smo zbog kuge mnoge (članove reda, op. a.) izgubili“". ${ }^{114}$ I inače, svećenstvo je zbog stalne interakcije s bolesnima radi obavljanja svoje pastoralne dužnosti, unatoč povećanim mjerama opreza, bilo izloženo potencijalnoj zarazi. Od šestorice iriških pravoslavnih svećenika čak polovica njih stradala je tijekom tzv. iriške kuge 1795/96. godine. ${ }^{115} \mathrm{U}$ istom mjestu je od 4813 stanovnika život u epidemiji izgubilo je čak njih 2548 (oko $53 \%$ ), ${ }^{116}$ odnosno smrtnost je bila jednaka kao i među svećenstvom. Hijerarhijski položaj u društvu izgleda nije bio dovoljna prepreka pred demokratičnosti epidemije kuge.

\section{Zaključak}

Mišljenje suvremenika XVIII. stoljeća da se u pojavi kuge ispoljava božja kazna ili pak da je ona djelo demona stavlja aktivnost svećenstva u prvi plan. Mnogobrojni primjeri duhovne brige svećenstva ostali su nam sačuvani u vizitacijama, kronikama i drugim zapisima, gdje se može prepoznati posvećenost molitvama namijenjenim spasu od epidemije kuge. Međutim, uloga svećenstva tijekom epidemija kuge ne može se svesti samo na duhovnu brigu za vlastitu pastvu.

Pored duhovne brige za vlastitu pastvu, svećenstvo je u borbi s kugom bilo nezaobilazan posrednik između svjetovnih vlasti i naroda. Masovna pojava nepoštivanja sanitarnih mjera mogla je biti savladana tek posredstvom onih koji su i sami dio društva kojemu su mjere upućene. Ustaljenu običajnu naviku bilo je teško promijeniti zbog mišljenja kako i samo neprovođenje određenih običaja može biti opasno koliko i epidemija kuge, ako ne i opasnije. No, sanitarno osoblje je preko lokalnog svećenstva to mišljenje nastoja-

${ }^{113}$ Edda Dubravec, Zdenko Samaržija, Društvena angažiranost redovničkih zajednica u Baranji, Slavoniji i Srijemu, (Osijek: Alberta, 2017), 74.

114 Stjepan Sršan ur., Kapucinski samostani u Osijeku, Beogradu. Zemunu i Novoj Palanki u prvoj polovici 18. stoljeća, /Zagreb; Osijek: Provincijalat hrvatske kapucinske provincije svetog Leopolda Bogdana Mandića, Zagreb, Centar „Leopold Mandić, Osijek, Državni arhiv u Osijeku, 2011), 83.

115 Jovan Maksimović i ostali, „O jevanđeljima u Irigu u vreme kuge 1795/96. godine“, Zbornik Matice srpske za istoriju, (2016) br. 94: 96.

116 Milorad Velisavljev, „Natalitet i mortalitet u Irigu u doba kuge 1795-1796 i danas“, u Zbornik radova: 200-godišnjica sremske-iriške kuge, ur. Vojislav Jovanović, (Novi Sad: Naučno društvo za istoriju zdravstvene kulture Vojvodine, 1996), 45. 
lo iskorijeniti, iako često ponavljanje identičnih naredbi pobuđuje sumnju u uspješnost toga procesa.

Pojava kuge na slavonsko-srijemskom području ili neposredno u blizini značila je i unošenje promjena u ustaljenu svećeničku praksu. Posjećivanje bolesnika bilo je ograničeno, a ispovijedanje provođeno s oprezom i pod određenim okolnostima. Uz to, svećenici su morali biti i uzor svima drugima.

Treba napomenuti kako je svećenstvo, točnije katoličko, značajno popunjavalo nedostatak medicinskog osoblja. S druge strane, pravoslavno je svećenstvo, iako nije imalo razvijenu medicinsku djelatnost kao ono katoličko, važnu ulogu odigralo u vrijeme epidemija kuge, aktivno sudjelujući u informiranju stanovništva te u zalaganju za provođenje sanitarnih mjera.

\section{Bibliografija}

\section{Objavljeni izvori}

Biber, Egidije Stjepan, ur. Kronika Franjevačkog samostana u Brodu na Savi. knj. 1, Slavonski Brod: Matica Hrvatska, Ogranak Slavonski Brod; Franjevački samostan Slavonski Brod; Povijesni arhiv Slavonki Brod, 1995.

Cvitković, Budimir, ur. Ljetopis franjevačkog samostana u Šarengradu. Šarengrad: Franjevački samostan Šarengrad, 2002.

Engel, Franz Stefan. Opis Kraljevine Slavonije i Vojvodstva Srema. Uredio Slavko Gavrilović. Novi Sad: Matica srpska, 2003.

Krstić, Vasa. „Naredbe načelnika Rumskog sreza za vreme kuge u Sremu 1795-1796 godine“, u: Prilozi za istoriju zdravstvene kulture Jugoslavije i Balkanskog poluostrva (Beograd: Biblioteka Centralnog higijenskog zavoda, 1940), 1-10.

Krstić, Vasa. „Okružnice sveštenstvu za vreme kuge u Sremu 1795 i 1796 godine“, u: Prilozi za istoriju zdravstvene kulture Jugoslavije i Balkanskog poluostrva (Beograd: Biblioteka centralnog higijenskog zavoda, 1940), 1-25.

Milošević, Miroslav; Novaković, Dušan; Novaković, Ivka. „Propisi za borbu protiv kuge u Pakracu 1796. godine“, Farmaceutski glasnik 35 (1979) br. 6, 195-203.

Schraud, Franz von. Istorija kuge u Sremu; 1795-1796. Preveo Jovan Valrabenštajn. Novi Sad: Naučno društvo za istoriju zdravstvene kulture Vojvodine, 1995.

Schraud, Franz von, Pichler, Joseph, Краткое поученіе како оть куги сачуватися мощи, 1795. Pristup ostvaren 11. 6. 2018., http://digital.bms.rs/ebiblioteka/pageFlip/reader/index. php?type=publications\&id $=560 \& \mathrm{~m}=2 \#$ page $/ 1 / \mathrm{mode} / 2$ up;

Sršan, Stjepan, ur. Kanonske vizitacije. knj. 8. Osijek: Državni arhiv u Osijeku, 2010. Sršan, Stjepan, ur. Kanonske vizitacije, knj. 5. Osijek: Državni arhiv u Osijeku 2007. Sršan, Stjepan, ur. Kanonske vizitacije, knj. 3. Osijek: Državni arhiv u Osijeku 2005. 
Sršan, Stjepan, ur. Kapucinski samostani u Osijeku, Beogradu, Zemunu i Novoj Palanki u prvoj polovici 18. stoljeća. Zagreb; Osijek: Provincijalat hrvatske kapucinske provincije svetog Leopolda Bogdana Mandića, Zagreb; Centar „Leopold Mandić, Osijek; Državni arhiv u Osijeku, 2011.

Sršan, Stjepan, ur. Osječki ljetopisi 1686.-1945. Osijek: Povijesni arhiv u Osijeku, 1993.

Stojanović, Ljubomir, ur. Stari srpski rodoslovi i letopisi. Sremski Karlovci: Srpska kraljevska akademija, 1927.

Taube, Friedrich Wilhem von. Povijesni i zemljopisni opis Kraljevine Slavonije i Vojvodstva Srijema. Priredio Stjepan Sršan. Osijek: Državni arhiv u Osijeku; Udruga povjesničara Slavonije i Baranje, 2012.

Tekelija, Sava. Dnevnik. Priredio Stevan Bugarski. Novi Sad: Matica srpska, 2011.

\section{Literatura}

Atalić, Bruno. „Spomenik Presvetoga Trojstva u gradu Osijeku“, Acta medico-historica Adriatica 15 (2017), br. Supplement 1: 83-98.

Bayer, Vladimir. Ugovor s đavlom. Procesi protiv čarobnjaka u Evropi a napose u Hrvatskoj. Zagreb: Informator, 1982.

Bugarski, Stevan. „Podaci o sremskoj kugi u zapisima Save Tekelije pri Madžarskoj dvorskoj kancelariji“. U: Zbornik radova: 200-godišnjica sremske-iriške kuge, uredio Vojislav Jovanović. Novi Sad: Naučno društvo za istoriju zdravstvene kulture Vojvodine, 1996, 19-37.

Cartwright, Frederick; Biddiss, Michael. Bolest i povijest. Prevela Lucija Horvat. Zagreb: Naklada Ljevak, 2006.

Cvetnić, Željko. Bolesti koje su mijenjale svijet. Zagreb: Medicinska naklada; Hrvatski veterinarski institut, 2018.

Čajkanović, Veselin. O vrhovnom bogu u staroj srpskoj religiji. Uredio Vojislav Đurić. Beograd: Srpska književna zadruga; Beogradski izgavačko-grafički zavod; Prosveta; Partenon M.A.M., 1994.

Delumeau, Jean. Strah na zapadu. Preveo Zoran Stojanović. Vrnjačka Banja: Zamak kulture, 1982.

Dubravec, Edda; Samaržija, Zdenko. Društvena angažiranost redovničkih zajednica u Baranji, Slavoniji i Srijemu. Osijek: Alberta, 2017.

Gavrilović, Slavko. Srem od kraja XVII do sredine XVIII veka. Novi Sad: Filozofski fakultet u Novom Sadu; Institut za istoriju, 1979.

Gavrilović, Vladan. „Podaci iz »Vukovarskog protokola« o sprečavanju prenošenja kuge u Srem 1762. godine“. U: Zbornik radova: Izvori o istoriji i kulturi Vojvodine. Uredio Dejan Mikavica. Novi Sad: Filozofski fakultet Novi Sad, 2009, 153-159. 
Horbec, Ivana. Zdravlje naroda - bogatstvo države. Prosvijećeni apsolutizam i počeci sustava javnoga zdravstva u Hrvatskoj. Zagreb: Hrvatski institut za povijest, 2015.

Ilić Oriovčanin, Luka. Narodni slavonski običaji. Uredio Željko Voborski. Novska: Gradsko poglavarstvo grada Novske, 1997.

Jovanović, Milan. Iz prošlosti Iriga. Irig: Srpska čitaonica, 1922.

Jovin, Slavko. Istorija medicine i zdravstvene kulture na tlu današnje Vojvodine 17181849. Novi Sad: Matica srpska, 1998.

Jovin, Slavko. „Uvođenje nadzora nad umrlima na teritoriji Vojvodine i stav Srpske pravoslavne Crkve“. Acta historica medicinae, pharmaciae, veterinae 20 (1980), br. 1/2, 201-202.

Kozobarić, Jovan. Spomenica Srpske pravoslavne crkve u Vukovaru-prigodom proslave dvesta godišnjice. Uredio Čedomir Višnjić. Zagreb: Srpsko kulturno društvo Prosvjeta, 2001.

Lovretić, Josip. Otok - narodni život i običaji. Uredila Manda Svirac. Vinkovci: Kulturno-informativni centar „Privlačica“, 1990.

Maksimović, Jovan. „Kuga u kulturnoistorijskim spomenicima“. U: Zbornik radova: 200-godišnjica sremske-iriške kuge. Uredio Vojislav Jovanović. Novi Sad: Naučno društvo za istoriju zdravstvene kulture Vojvodine, 1996, 56-101.

Maksimović, Jovan; Jelić, Darko; Novković, Vera; Jovičić, Branislav. „O jevanđeljima u Irigu u vreme kuge 1795/96. godine“. Zbornik Matice srpske za istoriju (2016) br. 94: 91-113.

Maksimović, Jovan. Srem u vreme kuge. Irig: Srpska čitaonica u Irigu, 2015.

Marković, Živko. „Irižani o kugi“. U: Zbornik radova: 200-godišnjica sremske-iriške kuge. Uredio Vojislav Jovanović. Novi Sad: Naučno društvo za istoriju zdravstvene kulture Vojvodine, 1996, 107-113.

Mikić, Petar. „Kuga u Karlovcima 1738-1740 i 1795/96“. Krovovi-bilten za kulturu i umetnost 21 (2007), br. 67/70, 25-29.

Obradović, Dositej. Život i priključenija. Uredio Goran Nakomčić. Novi Sad: Školska knjiga, 2004.

Ravančić, Gordan. Crna smrt 1348.-1349. u Dubrovniku - Srednjovjekovni grad i doživljaj epidemije. Doktorska disertacija, Sveučilište u Zagrebu, 2006.

Schneeweis, Edmund. Vjerovanja i običaji Srba i Hrvata. Prevela Dubravka Hrastovec. Zagreb: Golden marketing, 2005.

Simonović, Radivoj. Kuga u Sremu: godine 1795-1796. Priredio Živko Marković. Irig; Novi Sad: Srpska čitaonica; Budućnost, 1995.

Skenderović, Robert. „Kuga u Požegi i Požeškoj kotlini 1739. godine“. Scrinia Slavonica 3 (2003), 157-170.

Skenderović, Robert. Utjecaj terezijanskih reformi na demografski razvoj slavonskog Provincijala. Doktorska disertacija, Sveučilište u Zagrebu, 2005. 
Skenderović, Robert. „Zdravstvene reforme Marije Terezije u slavonskom Provincijalu i Generale normativum sanitatis iz 1770.“. Scrinia Slavonica 5 (2005), 115-143.

Velisavljev, Milorad. „Natalitet i mortalitet u Irigu u doba kuge 1795-1796 i danas“. U: Zbornik radova: 200-godišnjica sremske-iriške kuge, uredio Vojislav Jovanović 42-47. Novi Sad: Naučno društvo za istoriju zdravstvene kulture Vojvodine, 1996.

Walter, Francois. Katastrofe. Jedna kulturna istorija od XVI do XXI veka. Prevela Tamara Valčić Bulić. Novi Sad: Akademska knjiga, 2012.

Zečević, Slobodan. Srpska etnomitologija. Priredili Bojan Jovanović i Božidar Zečević. Beograd: Službeni glasnik, 2008. 


\section{Summary \\ THE ORTHODOX CLERGY OF SLAVONIA AND SYRMIA IN THE FIGHT AGAINST THE PLAGUE DURING THE $18^{\mathrm{TH}}$ CENTURY}

The inhabitants of the Slavonian-Syrmian area in the $18^{\text {th }}$ century had the misfortune to witness the horrors of the plague several times. The goods traffic and people passing through the border area such as the Slavonian-Syrmian were attended by the risk of transmitting disease. In order to prevent the spread of epidemics of the plague, during the $18^{\text {th }}$ century the Habsburg Monarchy built a cordon sanitaire at the state borders to stop the spread of epidemics. Despite all the security measures, it was not always possible to prevent the spread of an epidemic beyond the demarcation line. The population of the infected area was driven into despair by the ruthlessness and unknown etiology of the plague and by the absence of any effective treatment. The only salvation for the population was to invoke God and to hope for his assistance. The goal of the paper is to describe the role of Orthodox priests in circumstances in which the population could hope solely for divine assistance. The initial part of the paper explains the understanding of the plague epidemic among contemporaries, i.e. the interpretation of the epidemic as God's punishment or the influence of demons; this part is followed by a description of the spiritual care of the clergy expressed through prayer. Secular officials were eager to utilize the influence of the clergy on the populace and used the Orthodox clergy to implement and explain the expediency of certain sanitary measures. The interaction between the clergy and populace during epidemics of the plague required the adjustment of clerical activities. The final part of the paper is concerned with the role of the clergy in medical activities.

Keywords: plague, Slavonia, Syrmia, Orthodox clergy, $18^{\text {th }}$ century

(Translated by Mica Orban Kljajić)

\section{Kontakt autora:}

Veljko Maksić, mag. hist.

Koste Gajića 31, Vera

e-mail: veljkomaksic23@gmail.com 